\title{
Heat load model for small-scale CHP planning
}

\author{
E. Latõšov ${ }^{1}$, A. Siirde ${ }^{1}$ \\ ${ }^{1}$ Department of Heat Engineering \\ Tallinn University of Technology \\ Ehitajate tee 5, 19086 Tallinn (Estonia) \\ Phone: +372 620 2002, Fax number: +372 620 2020, e-mail: eduard.latosov@ttu.ee, asiirde@staff.ttu.ee
}

\begin{abstract}
.
Present-day world energy policy is based on two main directions: energy efficiency and environmental protection. Efficient Combined Heat and Power production is one of the energy consumption effective methods, where CHP production from the renewable fuels is preferable. [1]
\end{abstract}

In order to plan for the most economical, technical and environmental optimal CHP system, it is especially important to estimate the expected heat demands and heat load profiles for the district heating area.

This paper describes a method for estimation of heat load profile for a given district heating area by dividing it to three different heat load types:

- Temperature depended heat load;

- Constant heat load;

- User defined heat load.

The paper provides a complete description of above mentioned heat load types, equations as well as calculation examples. Calculation results are compared to hourly measured heat loads to estimate accuracy of a proposed model.

\section{Key words}

Cogeneration, district heating, heat load, temperature statistics, degree-hours.

\section{Introduction}

This paper draws on ongoing study 'Analysis on the technical and economic consequences of renewable energy based CHP systems in new areas with the lowered useful heat demand or after implementation of energy conservation measures in the areas with older buildings' within the Nordic Energy Research project 'Primary Energy Efficiency', which contributes to the effort of enhancing the primary energy efficiency (PEE) and reducing $\mathrm{CO}_{2}$ emissions in the energy sector.
The goal of study is to create a computer program to estimate economical and technical feasibility to build a CHP plant based on renewable fuels in Nordic/Baltic Sea Region countries taking into account the local conditions. The novelty of the planed computer program is an orientation to small scale (under $10 \mathrm{MW}_{\mathrm{el}}$ ) distributed CHP units, based on the existing district heating networks.

One of the 'core' issues, to model CHP activity, which affect on calculation results accuracy, is a heat load defining and modelling. This paper describes a method for estimation of heat load profile for a given district heating area.

The paper is structured as follows. After an overview of the heat load estimation principles, the paper will provide an overview of the main heat load types and their calculating principles. The last section will provide an district heating load simulation examples based on proposed model.

\section{Heat load estimation principles}

For the heat load simulation heat demand data and climate data is necessary. [2]

The heat demand can be established in several ways. For the consumers connected to the district heating system to which the heat has been supplied for many years already with their actual heat consumption being measured, the heat demand of previous years can be taken for the basis.

\section{Heat load types}

It is proposed, that district heating load consists of temperature-depended, constant and user-defined heat loads [3]. Every heat load type is formed by different heat load consumers (Fig. 1). 
Fig. 1. District heating heat load composition

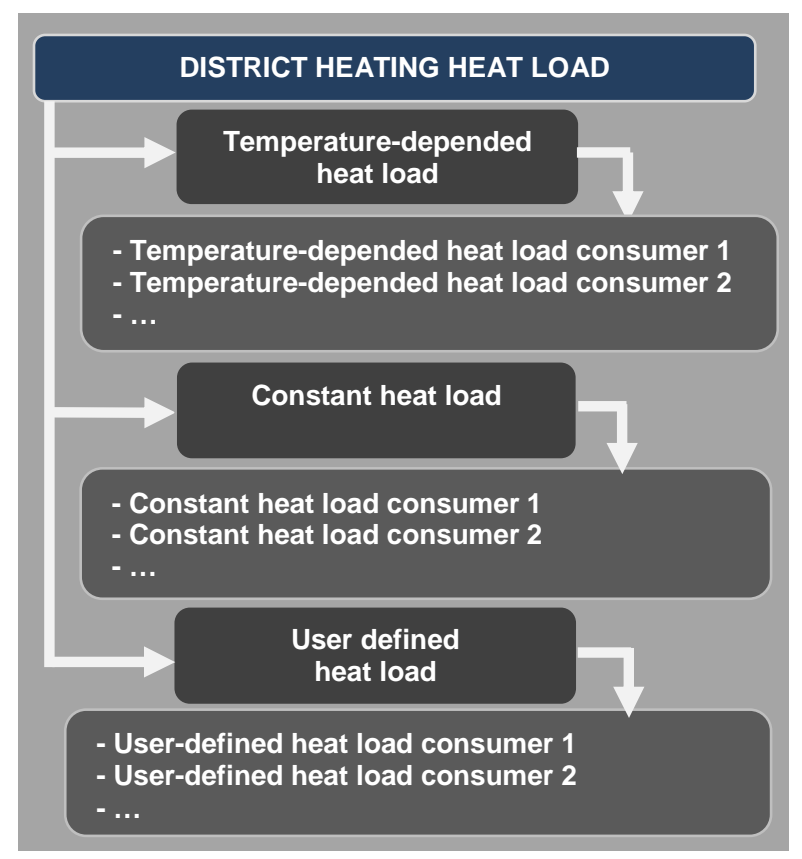

\section{A. Temperature-depended heat load}

Temperature-depended heat load (TDHL) is the most complicated part of the heat load modelling, where integration of the temperature datasets is necessary. Spaces heating as well as ventilation with, or without heat exchangers are good example of TDHL.

TDHL modelling is closely connected with degree hour term. [4]

A degree hour is simply the number of degrees spent above or below a standard reference temperature during the course of 1 hour [5].

Reference year degree-hours states;

$$
D H=\sum_{i=1}^{8760}\left(t_{r e f, n}-t_{i}\right)
$$

where:

$\mathrm{DH}$ - reference year degree-hours $\left[{ }^{\circ} \mathrm{C} \cdot \mathrm{h}\right]$

$t_{i}$ - reference year $i$ hours average outdoor temperature $\left[{ }^{\circ} \mathrm{C}\right]$

$t_{\text {ref }}$ - standard reference temperature for $n$ TDHL consumer $\left[{ }^{\circ} \mathrm{C}\right]$

$n \in 1$ toN, where $N$ is an amount of TDHL consumers for reference year.

Knowing reference year degree-hours and TDHL $n$ consumer annual heat consumption its heat consumption indicator is defined as;

$$
H C I_{n}=\frac{Q_{n}^{\text {temp }}}{D H}
$$

where:

$Q^{\text {temp }}{ }_{n}$ - TDHL $n$ consumer annual heat demand [MWh] $H_{C I}-n$ consumer temperature-depended heat consumption indicator $\left[\mathrm{MW} /{ }^{\circ} \mathrm{C}\right]$

Reference year $i$ hours average $n$ consumer temperature depended heat load states;

$$
P_{i, n}^{\text {temp }}=H C I_{n} \cdot t_{i}
$$

Reference year $i$ hours TDHL is defined as a summary of temperature-depended consumers $i$ hours heat loads;

$$
P_{i}^{\text {temp }}=\sum_{n=1}^{N} P_{i, n}^{t e m p}
$$

Reference year TDHL consumers' heat demand could be defined as;

$$
Q^{\text {temp }}=\sum_{n=1}^{N} Q_{n}^{\text {temp }}=\sum_{i=1}^{8760} P_{i}^{\text {temp }}
$$

\section{B. Constant heat load}

Constant heat load (CHL) does not change during the year. For the CHL works equality:

$P_{1, m}^{\text {const }}=P_{2, m}^{\text {const }}=\ldots=P_{8759, m}^{\text {const }}=P^{\text {const }}{ }_{8760, m}=P_{m}^{\text {const }}$

where:

$P^{\text {const }}{ }_{m}$ - CHL $m$ consumer heat load for reference year [MW];

$m \in 1$ to $M$, where $M$ is an amount of CHL consumers for reference year.

CHL $m$ consumer heat load defined as;

$$
P_{m}^{\text {const }}=\frac{Q^{\text {const }}{ }_{m}}{8760}
$$

where:

$Q^{\text {const }}{ }_{m}-\mathrm{CHL} n$ consumer annual heat demand [MWh]

There are no examples for CHL in its pure form. But with some exceptions heat loses in district heating network, as well as daily warm water mean consumption could be considered as a CHL. [8]

Reference year CHL states:

$$
P^{\text {const }}=\sum_{m=1}^{M} P_{m}^{\text {const }}
$$

Reference year CHL consumers' heat demand defined as; 
$Q^{\text {const }}=\sum_{m=1}^{M} Q_{m}^{\text {const }}=\sum_{m=1}^{M} 8760 \cdot P_{m}^{\text {const }}$

\section{User-defined heat load}

User-defined heat load (UDHL) is the most flexible way to define heat loads for CHP. At the same time UDHL implies, that heat load is more or less defined for every hour of the reference year. Industrial heat loads are great example of UDHL.

Reference year $i$ hours UDHL heat load defined as;

$P_{i}^{u s e r}=\sum_{l=1}^{L} P_{i, l}^{\text {user }}$

where:

$P_{i, l}^{\text {user }}$ - reference year $i$ hours TDHL $l$ user heat load [MW]

$l \in 1$ toL, where $L$ is an amount of UDHL consumers for reference year.

Reference year UDHL consumers' heat demand states;

$Q^{u s e r}=\sum_{l=1}^{L} Q_{l}^{u s e r}=\sum_{i=1}^{8760} P_{i}^{u s e r}=\sum_{i=1}^{8760} \sum_{l=1}^{L} P_{i, l}^{\text {user }}$

\section{District heating heat load}

District heating heat load for reference year $i$ hour is a sum of reference year $i$ hour heat loads. It defined as;

$P_{i}=P_{i}^{\text {temp }}+P^{\text {const }}+P_{i}^{\text {user }}$

where:

$P i$ - district heating heat load for reference year $i$ hour [MW]

District heating reference year annual heat demand defined as;

$$
Q=Q^{\text {temp }}+Q^{\text {const }}+Q^{\text {user }}=\sum_{i=1}^{8760} P_{i}
$$

Generalized equation for reference year district heating heat load for $i$ hour states;

$$
P_{i}=\sum_{n=1}^{N} \frac{Q^{\text {temp }}{ }_{n}}{\sum_{i=1}^{i=8760}\left(t_{r e f}-t_{i}\right)} \cdot t_{i}+\sum_{m=1}^{M} \frac{Q^{\text {const }}{ }_{m}}{8760}+\sum_{l=1}^{L} P_{i, l}^{\text {user }}
$$

\section{District heating heat load simulation}

Equation (13) will be used as a basis for district heating heat load simulation. It will be simplified and adopted for district heating networks of Estonian cities:

- Tallinn city district heating;

- Kuressaare city district heating.
Trial calculation will be compared to hourly measured respective district heating networks heat loads and an accuracy of results will be defined.

\section{A. Tallinn city district heating}

Tallinn city district heating annual heat demand for year 2008 was $2034951 \mathrm{MWh}$ (value obtained from Tallinn district heating operator Tallinna Küte), where $15 \%$ from the total heat demand is hot water, $16 \%$ district heating heat losses. Remaining heat is used for heating and ventilation.

Let's assume, that hot water preparation and heat loses are CHL consumers, and district heating and ventilation is a TDHL consumer.

Standard reference temperature for TDHL is $18^{\circ} \mathrm{C}$ [7].

Tallinn hourly temperature database is obtained from Estonian Meteorological and Hydrological Institute.

Regarding to initial data equation 13 could be simplified;

$$
P_{i}=\frac{Q^{\text {temp }} 1}{\sum_{i=1}^{i=8760}\left(t_{r e f}-t_{i}\right)} \cdot t_{i}+\sum_{m=1}^{2} \frac{Q^{\text {const }}{ }_{m}}{8760}
$$

where:

$\mathrm{Q}^{\text {temp }}=1404116 \mathrm{MWh}$;

$\mathrm{Q}^{\text {const }}=305243 \mathrm{MWh}$;

$\mathrm{Q}_{2}^{\text {const }}=325592 \mathrm{MWh}$;

$\mathrm{T}^{\mathrm{ref}}=18^{\circ} \mathrm{C}$

Trial calculation results and comparison to hourly measured district heating heat demand are shown in Figure 2.

Fig. 2. Tallinn city district heating network heat load profile

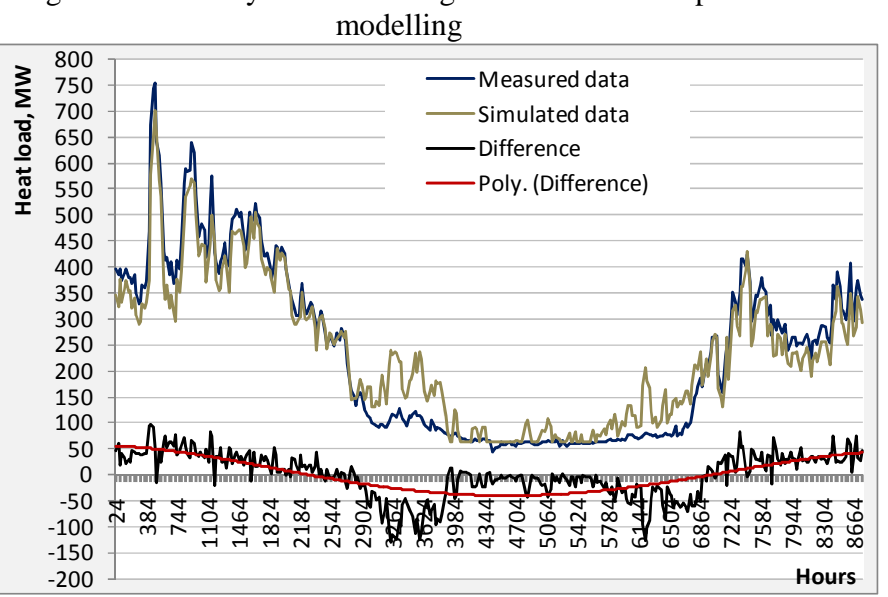

\section{B. Kuressaare city district heating}

Kuressaare city district heating annual heat demand for year 2008 was $80080 \mathrm{MWh}$ (value obtained from Kuressaare district heating operator Kuressaare soojus), where $15 \%$ from the total heat demand is hot water, $8 \%$ 
district heating heat losses [9]. Remaining heat is used for heating and ventilation.

Regarding to initial data equation 13 could be simplified to equitation (14), where:

$\mathrm{Q}^{\mathrm{temp}}=61606 \mathrm{MWh}$

$\mathrm{Q}^{\text {const }}=12001 \mathrm{MWh}$;

$\mathrm{Q}_{2}^{\text {const }}=6401 \mathrm{MWh}$;

$\mathrm{T}^{\mathrm{ref}}=18^{\circ} \mathrm{C}$. [7]

Kuressaare hourly temperature database is obtained from Estonian Meteorological and Hydrological Institute.

Trial calculation results and comparison to hourly measured district heating heat demand are shown in Figure 3.

Fig. 3. Kuressaare city district heating network heat load profile modelling

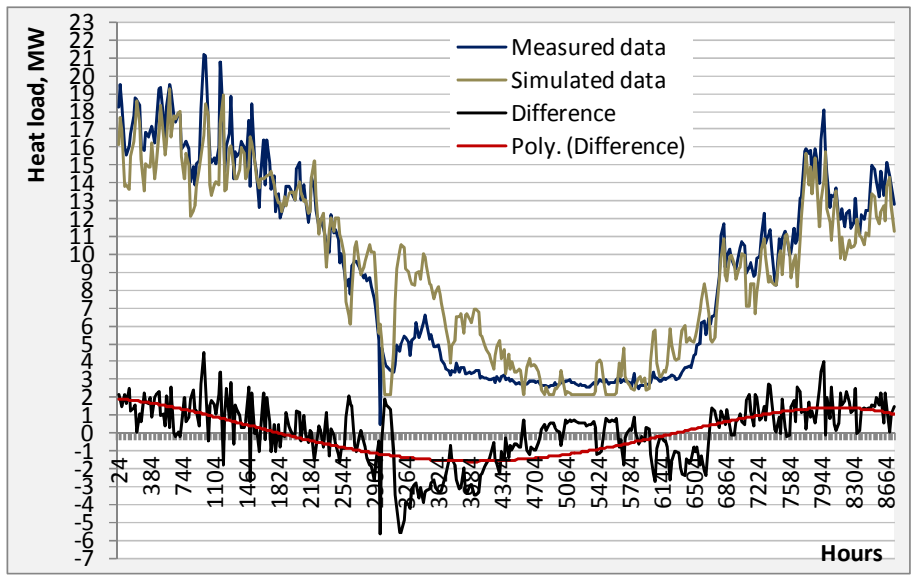

\section{Conclusion}

The advantage of proposed district heating load modelling method is simplicity of use in most cases, (district heating consumers could be more or less classified as constant, or temperature depended heat load consumers).

This method is suitable for pre-feasibility and feasibility studies where district heating load profile modelling is necessary and uncertainty level presuppose certain inaccuracy of modelling.

Trial calculations show that simulated and measured district heating network load profiles are very close to each other. As an exception there are transitional periods (late spring and the beginning of autumn), when simulated heat loads are higher than measured values.

For the future, proposed model could be improved by using correction factors to increase an accuracy of transitional periods modeling. Correction factor should consider a contribution of the coldwater temperature, the solar irradiation, the wind speed and other factors which affects to heat load profile formation. [6]

\section{References}

[1] C.Dötsch and A. Jentsch, "District heating (DH) in areas with low heat demand density (HDD): A chance for the integration of renewable energy sources (RES)", $10^{\text {th }}$ International Symposium on District Heating and Cooling, 3-5 September 2006,p.2.

WWW: http://www.lsta.lt/files/events/20_doetsch.pdf (20.01.2010)

[2] L. Haiyan and P. Valdimarsson, ,District heating modelling and simulation“", in PROCEEDINGS, Thirty-Fourth Workshop on Geothermal Reservoir Engineering Stanford University, Stanford, California, February 9-11, 2009 SGP-TR-187, pp.1. WWW:

http://pangea.stanford.edu/ERE/pdf/IGAstandard/SGW/2009/lei .pdf (20.01.2010)

[3] L. Pedersen and R. Ulseth, "Method for load modelling of heat and electricity demand", $10^{\text {th }}$ International Symposium on District Heating and Cooling, 3-5 September 2006, p.4. WWW: http://www.lsta.lt/files/events/26_pedersen.pdf (20.01.2010)

[4] G. L. Taylor, Construction codes and inspection handbook (2006) p. 575.

[5] Finnish energy industries, Correct use of district heat, Helsinki (2007) p. 6

WWW:

www.energia.fi/content $/$ root $\% 20$ content/energiateollisuus/fi $/ \mathrm{ka}$ ukolampo/kirjasto/julkaisut/liitteet/correctuseofdistrictheat.pdf?

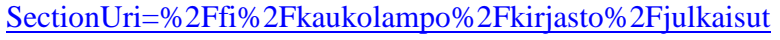
(20.01.2010)

[6] L. Saarinen, Modelling and control of a district heating system, Uppsala University, Uppsala (2008), p. 13. WWW:

http://www.svenskfjarrvarme.se/download/5286/8)\%20Modelli ng\%20and\%20control\%20of\%20a\%20.pdf (20.01.2010)

[7] T.-A.Kõiv, "Eesti kraadpäevad ja nende kasutusjuhend", Tallinn University of Technology (2003), p.3.

WWW:

http://www.mkm.ee/failid/eesti_kraadp_evad_2003_03_eeluuri ng.pdf (20.10.2010)

[8] The Danish Ministry of Economy and Business Affairs/Danish Energy Authority "Master Plan for Legionowo" (2003), p.8.

WWW: http://130.226.56.153/rispubl/NEI/NEI-DK-4427.pdf $(20.10 .2010)$

[9] Aktsiaselts Kuressaare Soojus, district heating company webpage.

WWW: http://www.kuressaaresoojus.ee/paged/firmast.htm (20.10.2010) 